\title{
Optimization of extrusion process for production of nutritious pellets
}

\author{
Otimização do processo de extrusão para a produção de pellets nutricional \\ Ernesto AGUILAR-PALAZUELOS ${ }^{1}$, José de Jesús ZAZUETA-MORALES ${ }^{1}$, \\ Elizabeth Nabeshima HARUMI², Fernando MARTÍNEZ-BUSTOS ${ }^{3 *}$
}

\begin{abstract}
A blend of 50\% Potato Starch (PS), 35\% Quality Protein Maize (QPM), and 15\% Soybean Meal (SM) were used in the preparation of expanded pellets utilizing a laboratory extruder with a $1.5 \times 20.0 \times 100.0 \mathrm{~mm}$ die-nozzle. The independent variables analyzed were Barrel Temperature (BT) $\left(75-140^{\circ} \mathrm{C}\right)$ and Feed Moisture (FM) (16-30\%). The effect of extrusion variables was investigated in terms of Expansion Index (EI), apparent density (ApD), Penetration Force (PF) and Specific Mechanical Energy (SME), viscosity profiles, DSC, crystallinity by $\mathrm{X}$-ray diffraction, and Scanning Electronic Microscopy (SEM). The PF decreased from 30 to $4 \mathrm{kgf}$ with the increase of both independent variables (BT and FM). SME was affected only by FM, and decreased with the increase in this variable. The optimal region showed that the maximum EI was found for BT in the range of $123-140{ }^{\circ} \mathrm{C}$ and $27-31 \%$ for FM, respectively. The extruded pellets obtained from the optimal processing region were probably not completely degraded, as shown in the structural characterization. Acceptable expanded pellets could be produced using a blend of PS, QPM, and SM by extrusion cooking.
\end{abstract}

Keywords: extrusion; expansion; third-generation-snacks; potato-starch; quality-protein-maize; soybean-meal.

\section{Resumo}

Neste trabalho foram elaborados pellets expandidos a partir da mistura de 50\% de Amido de Batata (AB), 35\% de Milho de Qualidade Protéica (MQP) e 15\% de Farelo de Soja (FS), utilizando extrusor de laboratório com matriz de 1,5 × 20,0 $\times 100,0 \mathrm{~mm}$. As variáveis independentes analisadas foram: Temperatura de Extrusão (TE) $\left(75-140^{\circ} \mathrm{C}\right)$ e Umidade da Mistura (UM) (16-30\%). O efeito das variáveis de extrusão foram estudadas quanto ao Îndice de Expansão (IE), a densidade aparente (DA), força de penetração (FP), Energia Mecânica Específica (EME), perfil de viscosidade, DSC, cristalinidade através de difração de raio X e Microscopia Eletrônica de Varredura (MEV). A PF diminuiu de 30 para $4 \mathrm{kgf}$ com o aumento de ambas as variáveis independentes (TE e UM). EME foi afetada somente pela UM, diminuindo com o aumento desta variável. A região otimizada mostrou que os melhores resultados foram obtidos utilizando TE na faixa de $123-140{ }^{\circ} \mathrm{C}$ e $27-31 \%$ UM, respectivamente. Pellets expandidos com características aceitáveis foram obtidos usando a mistura de amido de batata, milho de qualidade protéica e farelo de soja através de extrusão termoplástica.

Palavras-chave: extrusão; expansão; snacks de terceira geração; amido de batata; milho de qualidade protéica; farinha de soja.

\section{Introduction}

In recent years, the demand for snacks with improved nutritional and functional properties has increased. Among these products, expanded pellets have gained preference among both consumers and producers (SUKNARK; PHILIPS; HUANG, 1999; ERNOULT; MORARU; KOKINI, 2002). Non-expanded pellets are generally formed by extruding starches, flours, or blends of both. The extrusion process is carried out under moderately high moisture contents (30-35\%), low to reasonable shear, and barrel temperature and die temperatures $<100{ }^{\circ} \mathrm{C}$. As they are cooled and dried at $10-11 \%$ moisture content, the extruded pellets become glassy and very stable, and they can be expanded by baking, deep-fat frying, or microwave heating. (SUKNARK; PHILIPS; HUANG, 1999; ERNOULT; MORARU; KOKINI, 2002; VAN HULLE; ANKER; FRANSSELL, 1981;
SPRATT; TIMBERS; PATON, 1988; CHEN; YEH, 2000). Compared with hot-oil frying expansion, microwave-heated expanded pellets do not contain fat. Non-expanded pellets are very stable when stored and have high density, thus facilitating handling since great amounts of products occupy small volumes of storage space (HOLLINGSWORTH, 2001). Diverse efforts have been made to improve the nutritional value of snacks by means of incorporating protein from different sources. (FAUBION; HOSENEY, 1982; ONWULATA et al., 1998; MATHEW; HOSENEY; FAUBION, 1999; ALAVI et al., 1999; LI; LEE, 1996; CHANG et al., 2001; HASHIMOTO et al., 2002). Faubion and Hoseney (1982) observed that the effect of proteins on expansion depends on their type and concentration. Mathew, Hoseney and Faubion (1999) found that a decrease in protein

\footnotetext{
Received 12/1/2010

Accepted 15/11/2010 (004619)

${ }^{1}$ Ciencia y Tecnología de Alimentos, Universidad Autónoma de Sinaloa, Culiacán, Sin., México

2 Instituto de Tecnologia de Alimentos, Centro de Tecnologia de Cereais e Chocolates - Cereal Chocotec, Campinas, SP, Brasil

3 Departamento de Materiales, Centro de Investigación y Estudios Avanzados - CINVESTAV, Apdo. Postal 1-798, 76230, Santiago de Querétaro, Qro, México, e-mail:fmartinez@qro.cinvestav.mx

*Corresponding author
}

DOI: http://dx.doi.org/10.1590/S0101-20612012005000005 
content in corn meal benefited extrudate expansion due to the increase in starch content. According to Onwulata et al. (1998) and Onwulata et al. (2001), a maximum of 25\% Whey Protein Concentrate (WPC) added to corn, rice, or potato flour improved expansion through changes in extrusion shear and moisture, while concentrations higher than $25 \%$ reduced expansion. In addition, the incorporation of chickpeas into rice flour decreased product expansion (BHATTACHARYA; PRAKASH, 1994). Soybeans are a good source of biologically active phytochemicals, which have great potential to prevent chronic diseases (POTTER, 1998). Quality protein maize is a genotype with a high frequency of modifier genes, which confer high levels of lysine and tryptophan to the protein. It has similar agronomic characteristics to normal maize (BJARNASON; VASAL, 1992), and it has good characteristics for direct expansion using extrusion-cooking (MARTINEZ-BUSTOS; FIGUEROA; LARIOS, 1996). Moreover, according to Camire, Camire and Krumhar (1990) and Zazueta-Morales et al. (2001), snacks can be used as a vehicle to increase nutritional value by incorporating nutrients such as protein and fiber, which have health benefits. Therefore, the aim of this research was to optimize the effects of barrel temperature and feed moisture on some functional and technological characteristics of extruded pellets expanded by microwave heating.

\section{Materials and methods}

\subsection{Raw materials}

Official methods of Association of Official Analytical Chemists (1990) were used to analyze moisture (925.09), protein (979.09), lipid (923.05), fiber (962.09), and ash (923.03) contents. The amylose content was determined using the iodine affinity method (KNUTSON, 1986). Potato Starch (PS) was acquired from National Starch, Co. (Hammond, IN). Soybean meal (SM) (S-100 OGDEN, grown in the State of Illinois, USA, 2002) was donated by Cargill of Mexico. Quality protein maize (QPM) (grown in the State of Guanajuato, México, 2002) was donated by INIFAP from Celaya, Gto. The chemical composition (\%, means of two repetitions) of the potato starch, soybean meal, and decorticated quality protein maize was: moisture $12.96,5.85,4.80$; proteins $(\mathrm{N} \times 6.25) 0.17$, 51.24, 7.90; lipids 0.11, 1.69, 3.64; fiber 0.085, 3.57, 1.87; and ash $0.34,8.17,1.32$, respectively. Amylose content was $24.7 \%$ for potato starch and $23 \%$ for quality protein maize.

\subsection{Preparation of samples}

Maize grain was decorticated according to the methodology of San Martin-Martinez et al. (2003). Clean maize grain (5 kg) was steeped in water $(1: 0.8 \mathrm{w} / \mathrm{w})$ with vigorous agitation at $25{ }^{\circ} \mathrm{C}$, steeping temperature, and 8 minutes of steeping time. The steeped grain was fed into a continuous decorticating device keeping the residence time constant at 1 minute, and the screw speed at $800 \mathrm{rpm}$. The fractions were separated using pneumatic equipment. The fraction which passed through a $1.19 \mathrm{~mm}$ mesh sieve was separated, and the fraction retained was milled using a hammer mill (Pulvex, model 200, México) with a $0.8 \mathrm{~mm}$ sieve. The blend was prepared by mixing 50\% Potato Starch (PS), 35\% Quality Protein Maize (QPM), and 15\% Soybean Meal (SM).

\subsection{Extrusion and expansion processes}

Extrusion experiments were performed using a laboratory single extruder (model GNF 1014/2, Brabender, Inc., Duisburg, Germany) with three heating zones, a $380 \mathrm{~mm}$ long and $19 \mathrm{~mm}$ diameter extruder barrel, and a compression ratio of 2:1. A rectangular die with internal measurements of $1.5 \times 20 \times 100 \mathrm{~mm}$ long was used. The barrel temperature in the cooking zone (intermediate zone) was varied according to the experimental design, ranging from 75 to $140{ }^{\circ} \mathrm{C}$. The temperature in the initial zone (feed zone) and zone die (zone output) was maintained constant at 60 and $90^{\circ} \mathrm{C}$, respectively. The feed moisture varied from 16 to $30 \%$. The feed rate was maintained constant at $47.3 \pm 2.36 \mathrm{~g}$ and a screw speed of $103 \mathrm{rpm}$. These variables were fixed based on preliminary experiments. Non-expanded pellets were obtained from the extrusion process.

The extruded pellets were dehydrated before expansion at 9.5-10.5\% moisture (d.b.) $\left(50{ }^{\circ} \mathrm{C}\right.$ for 18 hours), cut into $2 \mathrm{~cm}$ pieces, and expanded by microwave heating for 25 seconds in a conventional microwave oven (Samsung, model MW843WA, $1200 \mathrm{~W}$ and $60 \mathrm{~Hz}$ ). These conditions were established on the basis of preliminary studies.

\subsection{Physicochemical characterization}

\section{Expansion index (EI)}

The Expansion Index (EI) was calculated by dividing the average transversal area of the expanded products by the average transversal area of the non-expanded products. Each assay was the mean of 15 repetitions.

\section{Apparent density}

Apparent density was determined according to the method of Gujska and Khan (1991) by weighing and dividing the weight of a sample by its apparent volume. Apparent volume is the average transversal area of the expanded products by the average length of the expanded products. Each assay was the average of 15 samples.

\section{Penetration force (PF)}

A universal TA-XT2 Texture Analyzer (Texture Technologies Corp., Scarsdale, NY, USA/Stable Micro System, Godalming, Surrey, UK) was used in compression puncture mode to record the force required to penetrate the expanded pellets (kgf). The expanded samples $(5 \mathrm{~cm}$ length) were placed transversally on a platform over a $1 \mathrm{~cm}$ thick metal sheet and punctured with a $2 \mathrm{~mm}$ diameter cylindrical flat-end punch at a speed of $2 \mathrm{~mm} / \mathrm{second}$ to a $3 \mathrm{~mm}$ penetration distance. Twenty-two repetitions were done per treatment.

\section{Specific mechanical energy (SME)}

It is a numerical value expressed as energy by unit weight $\left(\mathrm{J} \cdot \mathrm{g}^{-1}\right)$, which gives an idea of the severity of the process and the possible changes that could occur in the extrusion process. SME 
was calculated using the values for torque $(T, \mathrm{Nm})$, extruder screw speed $(s, \mathrm{rpm})$, and feed rate $(F, \mathrm{~g} /$ minute) (Equation 1$)$ :

$S M E=\frac{\left(2 \pi * T^{*} s\right)}{F}$

SME is defined as the net mechanical power input divided by the mass flow rate $\left(\mathrm{J} . \mathrm{g}^{-1}\right)$ required by the extruder to run the screw. SME provides very useful information for extrusion operations (BATTERMAN-AZCONA; LAWTON; HAMAKER, 1999).

\subsection{Experimental design and data analysis}

A two-factor central composite rotatable design with an $\alpha$ value of 1.414 was used. All assays were performed randomly (Table 1). Regression and variance (ANOVA) analyses were conducted in order to fit the models, represented in the above equation, and to examine the statistical significance of the model terms. The adequacy of the models was determined using $\mathrm{R}^{2}$ (coefficient of determination), lack-of-fit test, and Coefficient of Variation (CV).

Optimization of the extrusion variables' contour plots was performed using the Design Expert software package (STATEASE, 2001) following the methods of Meuser, Van-Lengerich and Gimmler (1990) and Floros and Chinnan (1988). A second order polynomial was used to predict the experimental behavior (Equation 2):

$y i=b_{0}+b_{1} X_{1}+b_{2} X_{2}+b_{11} X_{11}+b_{22} X_{22}+b_{12} X_{1} X_{2}$

where: $y i=$ generic response; $b_{1} \cdots_{12}=$ regression coefficients; $X_{1}=$ barrel temperature, $X_{2}=$ feed moisture; $X_{11}=$ quadratic term of barrel temperature; and $X_{22}=$ quadratic term of feed moisture.

Pearson correlation analysis $(\mathrm{p}=0.05)$ was performed using STATISTICA for Windows version 5 (STATSOFT, 1995) (Data not shown).

\subsection{Characterization of the optimized expanded product}

\section{Chemical composition}

To evaluate the changes in the chemical composition obtained in the products of the optimization region, official methods (ASSOCIATION..., 1990) were used to analyze moisture (925.09), protein (979.09), lipid (923.05), fiber (962.09), and ash (923.03) contents.

\section{Structural characterization}

In order to observe structural changes in the obtained products of the optimization region, evaluations of X-ray, Profiles of viscosity, DSC, and SEM were made.

\section{Viscosity analysis}

The viscosity of raw materials and dried ground extruded pellets was determined using a Rapid Visco Analyzer 3C (Newport Scientific PTY LTD, Sydney Australia) according to Zeng et al. (1997) and following the equipment instruction
Table 1. Experimental design of the extrusion process for two factors.

\begin{tabular}{ccccc}
\hline Assay & \multicolumn{4}{c}{ Independent variables } \\
\cline { 2 - 5 } \cline { 5 - 5 } \cline { 4 - 5 } & \multicolumn{2}{c}{ Codified } & \multicolumn{2}{c}{ Decodified } \\
\cline { 2 - 5 } & $\mathrm{X}_{1}$ & $\mathrm{X}_{2}$ & $\begin{array}{c}\text { Barrel } \\
\text { temperature }\left({ }^{\circ} \mathrm{C}\right)\end{array}$ & $\begin{array}{c}\text { Feed } \\
\text { moisture }(\%)\end{array}$ \\
\hline 1 & -1 & -1 & 85 & 18 \\
2 & 1 & -1 & 130 & 18 \\
3 & -1 & 1 & 85 & 28 \\
4 & 1 & 1 & 130 & 28 \\
5 & -1.414 & 0 & 75 & 23 \\
6 & 1.414 & 0 & 140 & 23 \\
7 & 0 & -1.414 & 107.5 & 16 \\
8 & 0 & 1.414 & 107.5 & 30 \\
9 & 0 & 0 & 107.5 & 23 \\
10 & 0 & 0 & 107.5 & 23 \\
11 & 0 & 0 & 107.5 & 23 \\
12 & 0 & 0 & 107.5 & 23 \\
13 & 0 & 0 & 107.5 & 23 \\
\hline
\end{tabular}

manual of the (Newport Scientific 1999). The results were reported in RVUs, where 1 RVU=12 Centipoise.

\section{Differential scanning calorimetry}

A differential Scanning Calorimeter (DSC 822e, Birefrigerated, Mettler Toledo Lab Plant, Huddersfield, England) was used. The samples were heated from 40 to $100^{\circ} \mathrm{C}$ at a rate of $10^{\circ} \mathrm{C} /$ minute, and the transition enthalpy was measured.

\section{$X$-ray diffraction patterns}

Ground samples of raw materials and extruded pellets with 9.5 to $10.5 \%$ moisture content, which passed through a $250 \mu \mathrm{m}$ mesh sieve, were packed onto a glass sample plate ( $0.5 \mathrm{~mm}$ deep) and mounted onto a Siemens D500 Diffractometer. The scans were made from a Bragg angle of 5 to $35^{\circ}$ on a $2 \theta$ scale with a step-size of 0.02 , operating at $30 \mathrm{kV}$ and $16 \mathrm{~mA}$ with $\mathrm{CuK} \mu$ radiation wavelength $\lambda=1.5406 \AA$.

\section{Scanning electron microscopy}

The raw blend, extrudate, and expanded pellets were stored with silica at $35^{\circ} \mathrm{C}$ for 10 days to remove the residual moisture. Sections were stuck to stubs, coated with Au-Pd alloy in a high vacuum, and examined using a scanning electron microscope ZEISS, model DSM-950, and a secondary electron detector with $15 \mathrm{kV}$ of acceleration.

\section{Results and discussion}

\subsection{Physicochemical characteristics of expanded pellets}

Table 2 shows the analysis of variance for the Expansion Index (EI), apparent density (ApD), Penetration Force (PF), and Specific Mechanical Energy (SME). All physiochemical parameters evaluated showed a significant regression model, with values of $R^{2} \geq 0.88$, and coefficients of variation between 6.02 and 21.04 and value of $p<0.005$; and most did not show 
Table 2. Statistical models of the evaluated responses.

\begin{tabular}{|c|c|c|c|c|}
\hline & EI & $\operatorname{ApD}\left(\mathrm{kg} \cdot \mathrm{m}^{-3}\right)$ & PF (kgf) & SME (J.g $\left.{ }^{-1}\right)$ \\
\hline Intercept & +3.79 & +197.56 & +1.13 & +316.13 \\
\hline \multicolumn{5}{|l|}{ Linear } \\
\hline$b_{1}$ & $\begin{array}{c}0.53^{\star} \\
(<0.001)\end{array}$ & $\begin{array}{c}-70.32 \\
(<0.001)\end{array}$ & $\begin{array}{c}-0.91 \\
(<0.001)\end{array}$ & $\begin{array}{l}7.97 \\
\text { (NS) }\end{array}$ \\
\hline$b_{2}$ & $\begin{array}{l}0.12 \\
(\mathrm{NS})\end{array}$ & $\begin{array}{c}-5.74 \\
(\mathrm{NS})\end{array}$ & $\begin{array}{c}-0.44 \\
(<0.005)\end{array}$ & $\begin{array}{l}-167.28 \\
(<0.001)\end{array}$ \\
\hline \multicolumn{5}{|l|}{ Quadratic } \\
\hline$b_{11}$ & $\begin{array}{l}0.13 \\
\text { (NS) }\end{array}$ & $\begin{array}{c}-27.47 \\
(<0.005)\end{array}$ & $\begin{array}{l}-0.19 \\
(-0.04)\end{array}$ & $\begin{array}{c}3.42 \\
(<0.006)\end{array}$ \\
\hline$b_{22}$ & $\begin{array}{l}0.069 \\
\text { (NS) }\end{array}$ & $\begin{array}{l}15.82 \\
(\mathrm{NS}) \\
\end{array}$ & $\begin{array}{c}0.29 \\
(-0.089) \\
\end{array}$ & $\begin{array}{c}16.85 \\
(<0.003)\end{array}$ \\
\hline \multicolumn{5}{|l|}{ Interaction } \\
\hline$b_{12}$ & $\begin{array}{c}0.33 \\
(-0.034)\end{array}$ & $\begin{array}{c}-4.51 \\
(<0.001)\end{array}$ & $\begin{array}{l}0.23 \\
\text { (NS) }\end{array}$ & $\begin{array}{l}18.56 \\
\text { (NS) }\end{array}$ \\
\hline $\mathrm{R}^{2}$ & 0.88 & 0.93 & 0.93 & 0.98 \\
\hline C.V. & 6.39 & 9.01 & 21.04 & 6.02 \\
\hline F Value & 9.26 & 52.9 & 19.71 & 220.51 \\
\hline $\mathrm{P}$ of $\mathrm{F}$ & 0.005 & $<0.001$ & $<0.001$ & $<0.001$ \\
\hline Lack of fit & 0.131 & 0.635 & 0.003 & 0.06 \\
\hline
\end{tabular}

a significant lack of fit, except for PF. The statistical analysis (Table 2) indicated that BT was the variable that had the greatest effect on the parameters analyzed in both their linear $(\mathrm{p} \leq 0.001$, except SME) and quadratic terms ( $\mathrm{p} \leq 0.04$, except EI).

On the other hand, FM had an effect on PF and SME in their linear term and quadratic term. In addition, the interaction $\left(b_{12}\right)$ was significant only for EI and ApD.

\subsection{Expansion index (EI) and apparent density (ApD)}

Figures 1a,b show the effect of BT and FM on EI and ApD. An increase in BT increased EI and decreased ApD. Pearson correlation analysis indicated that $\mathrm{BT}$ and $\mathrm{ApD}$ showed inverse correlation $(r=-0.85, p<0.001)$. These results indicate that higher BT decreased ApD. Barrel temperature is one of the most important factors that contribute to starch modification during extrusion although excessive starch degradation decreases expansion (LEE et al., 2000). Case, Hamann and Schwartz (1992) reported a decrease in the density of expanded pellets when starch degradation was increased as a result of an increase in the barrel temperature.

The values of EI found in this research (3.25-5.24) were lower than those reported for corn and rice starches and similar (3.55-4.69) to those reported for potato flour (BASTOSCARDOSO et al., 2007), probably due to the addition of soybean meal in the blend that decreased the EI. In general, proteins act as diluents and reduce expansion due to their ability to affect water distribution in the matrix, and to the fact that their macromolecular structure and conformation affect the extensional properties of extruded meal. Protein content also contributes to the formation of extensive networking through covalent links and electrostatic interactions that take place during extrusion (LI; LEE, 1996; MADEKA; KOKINI, 1992).

Chang et al. (2001) reported that the highest values for axial expansion were found at the maximum Soy Protein
Concentrate (SPC) level in the blend with cassava starch and at the lowest feed moisture. Higher levels of SPC, greater than $25 \%$, reduced radial expansion. Moreover, the addition of gluten to cassava starch decreased the radial expansion of extrudates (HASHIMOTO et al., 2002), and in the same way the following blends decreased radial expansion: co-extrusion of corn meal, wheat starch, and rice and barley flours with whey protein (ONWULATA et al.,1998), wheat and corn starch with soy protein isolate (ONWULATA et al., 1998; FAUBION; HOSENEY, 1982), egg-white proteins and starch (ALAVI et al., 1999), chickpea and rice flours (BHATTACHARYA; PRAKASH, 1994), and cysteine and wheat flour (LI; LEE, 1996).

The values of $\mathrm{ApD}$ were inversely correlated to EI. Similar behavior was reported by Ascheri et al. (1995), who found that ApD was inversely related to EI and, therefore, to the degree of gelatinization of extruded pellets of corn starch, corn flour, and cassava starch. Lee et al. (2000) found that a gelatinization of about $50 \%$ is appropriate for the elaboration of expanded pellets. Under these conditions, it is likely that the air bubbles are formed more easily, and they expand by the increase of vapor pressure without rupturing (MORARU; KOKINI 2003).

\subsection{Penetration force (PF) and specific mechanical energy (SME)}

Figures $1 c, d$ show the effect of the barrel temperature and feed moisture on the Specific Mechanical Energy (SME) and Penetration Force (PF) of expanded pellets by microwave heating, respectively. PF decreased from 30 to 4 (kgf) with the increase in both factors. On the other hand, SME was not affected by BT, but it decreased with the increase in FM.

The response variable $\mathrm{PF}$ had moderate association $(\mathrm{r}=-0.67, \mathrm{p}=0.012)$ with EI, and significant association with ApD $(\mathrm{r}=0.84, \mathrm{p}<0.001)$. Case, Hamann and Schwartz (1992) reported that an increase in the gelatinization degree decreased the PF in the expanded pellets; they also added that extruded pellets with a high gelatinization degree had better characteristics of expansion and crunchy texture. The breaking force of the expanded products, particularly expanded snack foods, is an important factor for both the processor and the consumer. If the product has a low breaking force, it will break easily during packaging and distribution. On the other hand, if the product has a high breaking force, consumers will find the product difficult to bite and chew (MAGA; LIU, 1993). The breaking force can be directly related to the degree of starch gelatinization and degradation (CASE; HAMANN; SCHWARTZ, 1992), which in turn is temperature and feed moisture dependent (CHIANG; JOHNSON, 1977)

SME as the studied factor did not show correlation with the studied responses, whereas it showed important inverse association with FM ( $\mathrm{r}=-0.98, \mathrm{r}<0.001)$ (data not shown). SME is a good quantitative descriptor of the extrusion process since it allows direct comparison of different combinations of extrusion conditions such as screw speed, feeding rate, and torque. The amount of mechanical energy delivered to the extruded material determines the extent of macromolecular transformations and interactions that take place; that is, 

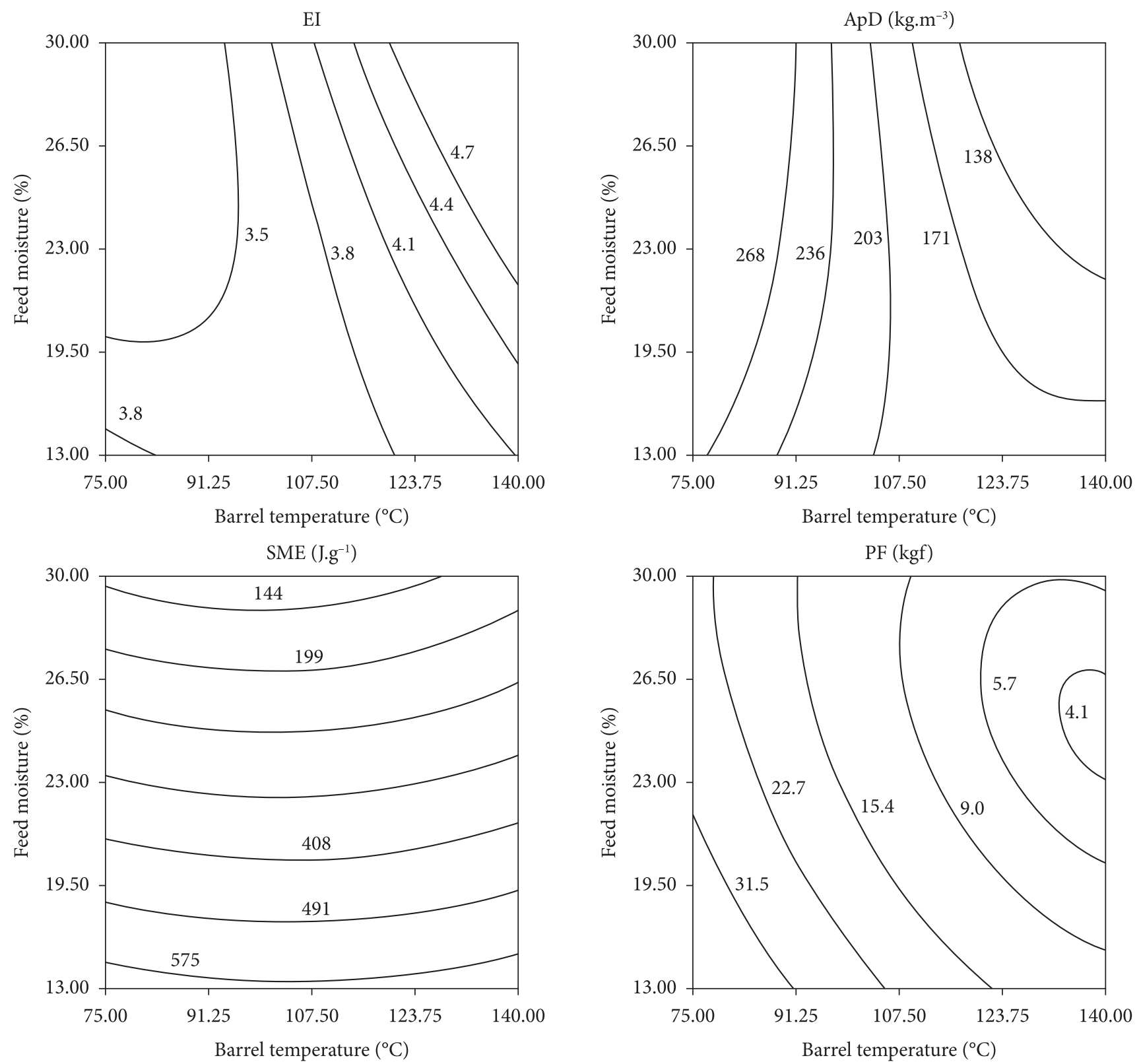

Figure 1. Effect of the barrel temperature and feed moisture on: EI = Expansion index; ApD = Apparent density; SME = Specific mechanical energy, and $\mathrm{PF}=$ Penetration force of expanded pellets by microwave heating.

starch conversion and consequently the rheological properties of the melt. The values of SME found at low feed moisture (Figure 1c) were similar to those reported by Boischot, Moraru and Kokini (2003) in third generation expanded amylopectin extrudates. Also, these researchers reported that SME values (483-846 kj.kg-1) did not influence expansion. According to these authors, this could be due to the relatively limited range of the extrusion variables used, which did not dramatically modify the properties of the pellets in terms of starch conversion and fragmentation. Zazueta-Morales et al. (2001) reported a direct correlation between SME with EI, ApD, and PF of direct expanded corn starch snacks and therefore with the degree of starch gelatinization. This may be due to the intrinsic factors of high feed moisture and the requirement to obtain partially degraded products during the elaboration of expanded pellets (LEE et al., 2000; SUNDERLAND, 1996).
The best treatments were found with barrel temperatures higher than $107.5^{\circ} \mathrm{C}$, also, these products showed high EI and low ApD and PF. Therefore, the ApD was inversely associated with EI and therefore with the severity of the extrusion process during the elaboration of expanded pellets. Sunderland (1996) indicated that the best characteristics of expanded pellets were obtained when the starch was partially degraded, and this researcher recommended barrel temperatures from 80 to $150^{\circ} \mathrm{C}$ and feed moisture from 25 to $30 \%$.

\subsection{Optimization}

Optimization was carried out by the superposition of several contour surfaces of competing responses. The criterion established to determine the critical radial expansion index value 
was to find the conditions leading to the maximum possible expansion and the lowest values of $\mathrm{ApD}, \mathrm{PF}$ and SME.

For expanded products used as snack foods, a good degree of expansion is required. For this reason, in the optimization procedure an EI value of 4.75 was considered the minimum acceptable, with maximum values of ApD and PF of $130 \mathrm{~kg} \cdot \mathrm{m}^{-3}$ and $5.83 \mathrm{kgf}$, respectively since these values were registered from an expanded wheat commercial snack. Thus, experimentally, the highest values of EI $(>4.0)$ were obtained at high barrel temperatures $\left(>130^{\circ} \mathrm{C}\right)$, while at temperatures lower than $130{ }^{\circ} \mathrm{C}$, the values of EI were lower than 4.0. The suitable maximum value for SME was $300 \mathrm{~J} . \mathrm{g}^{-1}$ since this level was the minimum consumption of energy in which snacks with high values of EI and low of ApD and PF were obtained. Figure 2 shows a shaded area that corresponds to the best conditions. The optimal conditions found were $128^{\circ} \mathrm{C} \mathrm{BT}, 28.0 \% \mathrm{FM}, 5.24 \mathrm{EI}$, $125 \mathrm{~kg} . \mathrm{m}^{-3} \mathrm{ApD}, 205 \mathrm{~J} . \mathrm{g}^{-1} \mathrm{SME}$, and $5.70 \mathrm{kgf}$ PF.

\subsection{Characterization of the optimized expanded product}

\section{Chemical composition}

The expanded product obtained in the optimized region had a moisture content of $90.9 \pm 2.29 \mathrm{~g} \cdot \mathrm{kg}^{-1}, 105.8 \pm 4.0 \mathrm{~g} . \mathrm{kg}^{-1}$ of protein, $31.0 \pm 0.8 \mathrm{~g} . \mathrm{kg}^{-1}$ of lipids, $17.0 \pm 1.1 \mathrm{~g}^{\mathrm{kg}} \mathrm{kg}^{-1}$ of ash, $13.6 \pm 0.3 \mathrm{~g} \cdot \mathrm{kg}^{-1}$ of fiber, and $860.5 \mathrm{~g} . \mathrm{kg}^{-1}$ of carbohydrates. The addition of soy and QPM increased the protein content without compromising the desired texture of the expanded snacks.

\section{Viscosity analysis}

Figure 3 shows the viscosity profiles of the raw materials and the extruded blends obtained in the optimized region. Potato Starch (PS) showed the highest viscosity peak - 585 RVU, followed by Quality Protein Maize (QPM) - 101 RVU, Soybean Meal (SM) - 0 RVU, and Raw Blend (RB) - 25 RVU. RB showed similar behavior to potato starch although with low viscosity values, probably due to the effect of denaturalized protein from $\mathrm{SM}$. The extrusion process decreased significantly the values of maximum viscosity for the blend from 146 to 34 RVU, which suggests that the starch was partially gelatinized. This showed viscosity values lower than the raw blend but without losing it completely (Figure 3). This is consistent with the findings of Lee et al. (2000). These researchers reported that the optimal expansion of extruded starch corn pellets, expanded by microwave heating, was found when the starch was gelatinized $\approx 50 \%$, and the equilibrium moisture content in the pellets was $\approx 10 \%$. The pellets were extruded in a co-rotating twin-screw extruder at $90{ }^{\circ} \mathrm{C}$ with a water injection rate of $63 \mathrm{~g} /$ minute. They added that for uniform distribution of small-sized air cells with good puffing efficiency, the pellets should have a vapor pressure buildup followed by sudden release (puffing) during microwave-heating. In addition, Ernoult, Moraru and Kokini (2002) reported a high degree of expansion on amylopectin extrudates with high initial $a_{w}$, and the moisture content increased EI as $a_{w}$ increased from 0.011-0.605 and decreased for $a_{w}$ values greater than 0.605 . According to these researchers, this effect was related to the mechanical properties of the matrix; a

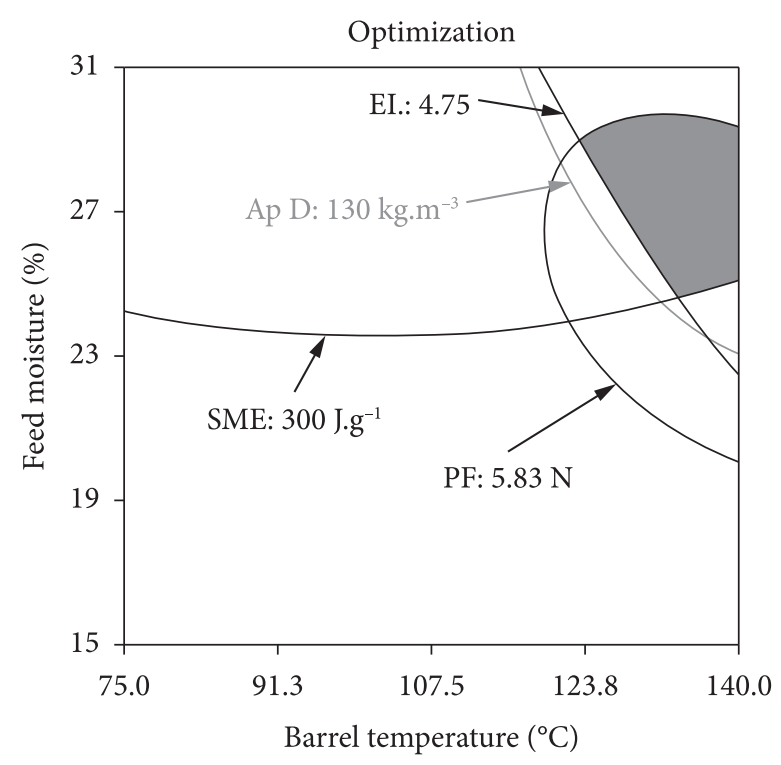

Figure 2. Superposition area of the responses as an effect of the barrel temperature and feed moisture on the extrusion process of third generation snacks.

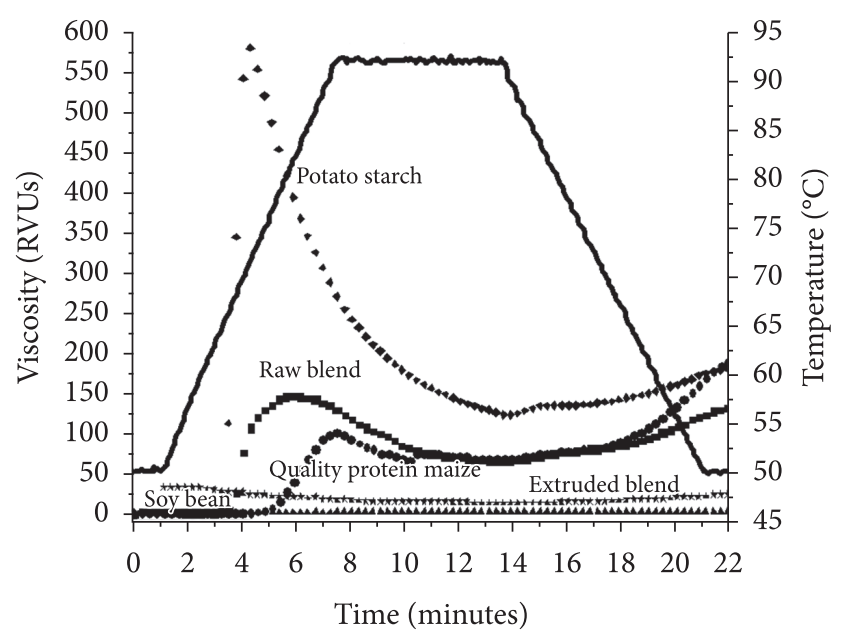

Figure 3. Viscosity profiles of the raw materials and extruded product obtained in the optimal region of processing (optimized).

pellet expands when pressure increases due to the moisture in its interior; however it tends to collapse if the matrix is very soft, which is the case for high moisture in pellets. Similarly, Chen and Yeh (2000) reported that expansion ratio was inversely related to the intrinsic viscosity of rice pellets, and it decreased as the amylose content increased, with maximum expansion at $10 \%$ equilibrium moisture due to the transition of the pellets from brittle to ductile.

\section{Differential scanning calorimetry}

The transition enthalpy $(\Delta \mathrm{H})$ values were $15.24 \mathrm{~J}^{\mathrm{g}} \mathrm{g}^{-1}$ for

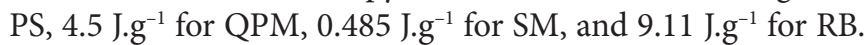
Thomas and Atwell (1997) reported that maize and potato native starches showed endotherms between $62-80^{\circ} \mathrm{C}$ and $52-85^{\circ} \mathrm{C}$, respectively, which were similar to the values found in this study. The extruded pellet processed in optimal conditions did 


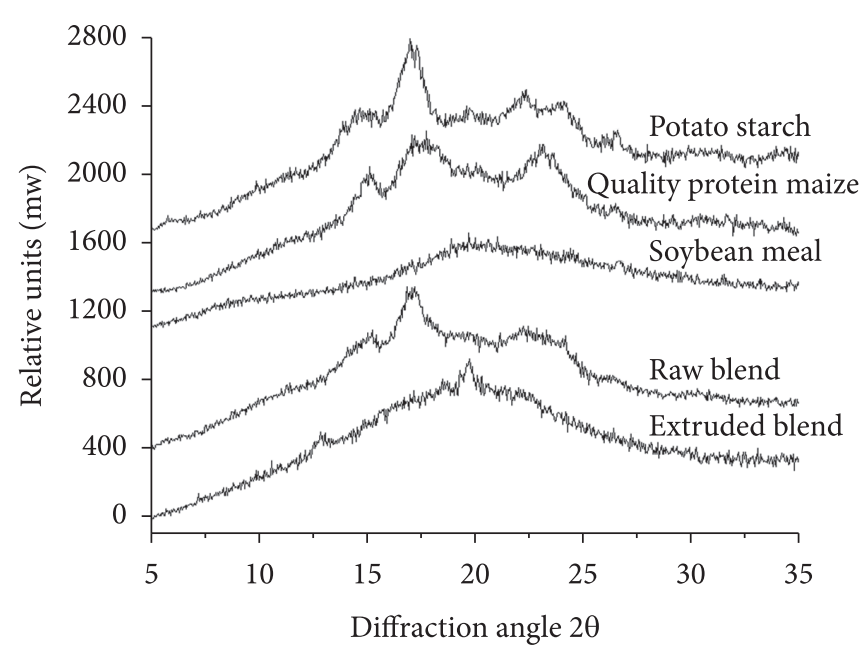

Figure 4. Difractograms of the raw materials and extruded product obtained in the optimal region of processing (optimized). not show any endothermic peak, probably due to the previous gelatinization that took place during the extrusion process. Similarly, Lee, Ryu and Lim (1999) reported that the starch gelatinization degree in extruded products at supercritical conditions was high when the barrel temperature was low. Thus, these researchers concluded that extruded products at $80{ }^{\circ} \mathrm{C}$ barrel temperature showed a low endothermic peak, whereas, when they were extruded at 90 or $100^{\circ} \mathrm{C}$, they did not show any endothermic peak. Moreover, Gomez and Aguilera (1984) found extensive starch degradation during extrusion when the feed moisture was decreased, and as a result, the obtained thermograms (DSC) did not show endothermic peak (endotherm). Hence, they postulated that the quantity of residual native starch was minimum in extruded products and undetectable by DSC methodology indicating that the absence of endothermic peak does not mean that the material was completely degraded. On the other hand, Wang et al. (1989) indicated that in order to explain the combined effects of moisture content and the source of the starch on the thermal
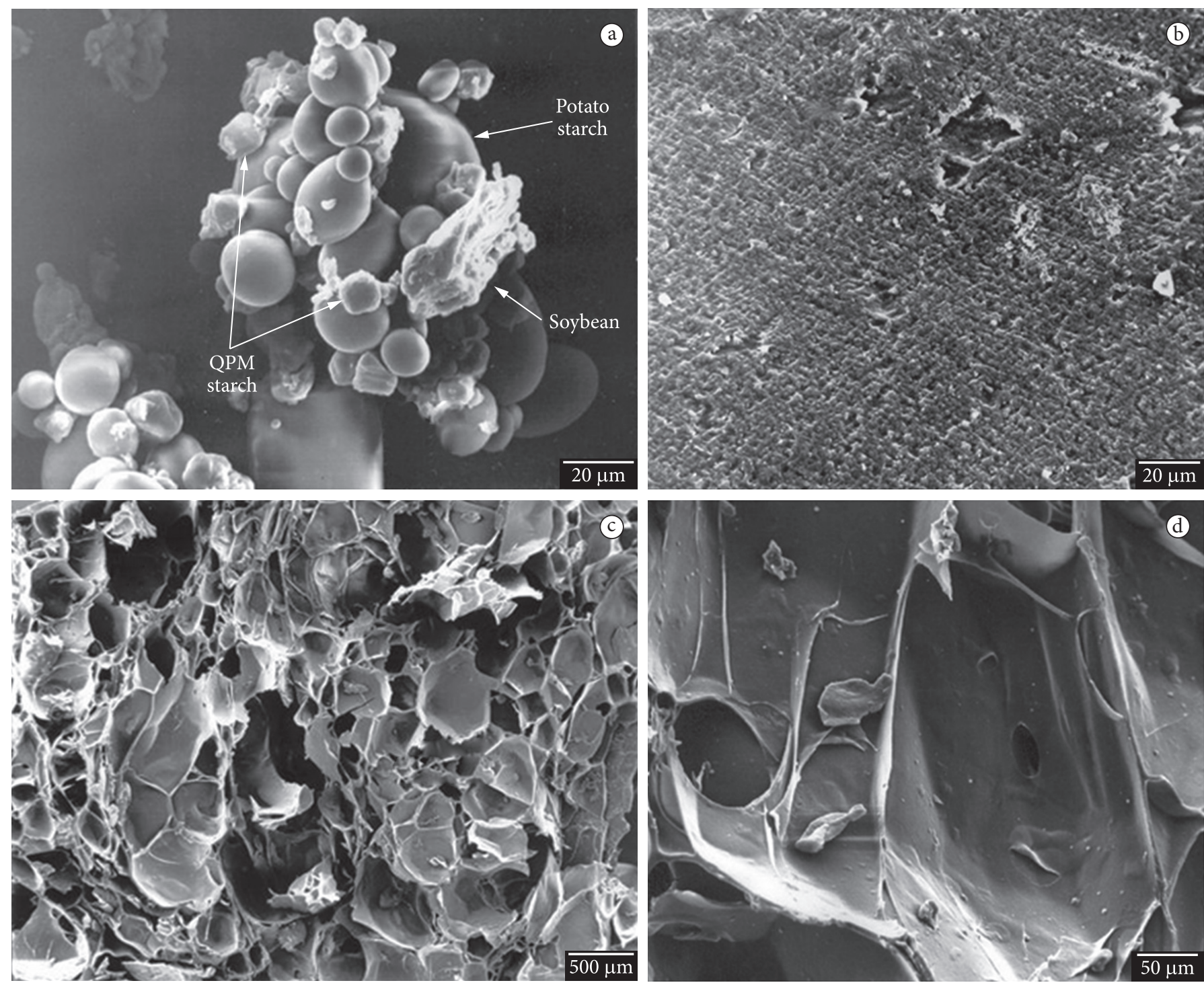

Figure 5. Microphotographs of: a) raw blend; b) nonexpanded pellet; and c,d) expanded extruded pellet by microwave heating 
transition of starch, a useful dimensionless parameter $T / \mathrm{Tg}$, was found, where $\mathrm{Tg}$ is the operating temperature for the reaction and $\mathrm{T}$, is dependent on the source of the starch and the moisture content in the sample. This parameter, $\mathrm{T} / \mathrm{Tg}$, can be used as an index for judging the effectiveness of thermal effect on the process of starch conversion. Nevertheless, in the present study, it was impossible to determine the Tp value necessary for this evaluation.

\section{X-ray diffractograms}

Figure 4 shows the patterns for cereals (A type) and tubercles (B type) corresponding to QPM and PS. SM showed a completely amorphous pattern, while RB showed a diffraction pattern with characteristics of A and B types. The extruded blend shows the loss of the pattern of the native raw materials and the formation of new crystallinity peaks due to the effects of the process. These peaks correspond to the $V_{h}$ structure, characteristic of extruded starches and are similar to the results of Singh et al. (1998), which were attributed to the formation of the amylose-lipid complex in extruded products. The same peaks were found in extruded pellets processed under the optimal conditions.

\section{Scanning electron microscopy (SEM)}

The most important changes that took place in the processed material apparently were degradation, gelatinization, and plasticization of starch granules. Figure 5 a shows the microphotographs of the raw blends. Corn starch granules are smaller than those of potato starch, with approximate diameters between 5-15 $\mu \mathrm{m}$ and between $15-50 \mu \mathrm{m}$, respectively. Moreover, protein bodies found in foam probably originate from the SM. In addition, there were small free particles that adhered to the surface of the starches, which could be oil globules or fiber fragments and probably originate from the milling process during particle reduction or from the partial decortication of the raw materials.

Figure 5b shows the microphotographs of the pellets obtained from the optimal region of processing. The starch granules were melted and plasticized, with some cavities in the surface of the pellets, which probably were occupied by water that evaporated during the extrusion process. This structure is similar to those reported by Sunderland (1996) in extruded pellets. The Figure $5 \mathrm{c}$ shows a microphotograph of a section of the expanded pellet using microwave heating obtained from the optimal region of processing. The fragment shows the porous structure of the expanded material and almost uniformly-distributed air cells (globules or bubbles) of gas (air) of uniform size. This structure is very similar to those found in expanded pellets using microwave heating and also similar to the structure reported for "popcorn" and expanded sorghum (LEE et al., 2000).

Figure $5 \mathrm{~d}$ shows a view of the internal wall of a cell or air bubble formed during the expansion by microwave heating. It shows a surface with topography of elevations, cavities, and perforations with a smooth wall texture. In the expanded pellets, the water held in the interior began to evaporate increasing the internal pressure of the product and consequently expanding it causing the air cells of the expanded product to extend and form walls with smooth surfaces. According to Lee et al. (2000), in pellets with insufficient gelatinization, the buildup of vapor pressure inside the pellet might not be sufficient due to vapor discharge. On the other hand, pellets with excess gelatinization might be expanded over an extended time resulting in continuous cell growth and thick cell walls.

\section{Conclusions}

The barrel temperature showed significant effects on the expansion index, apparent density, and penetration force, whereas the feed moisture had a significant effect on the specific mechanical energy. On the other hand, an increase in barrel temperature and a decrease in feed moisture favored the starch degradation in extruded products, as shown by the physiochemical analysis. The best conditions for preparation of expanded pellets made from blend of 50\% Potato Starch (PS), 35\% Quality Protein Maize (QPM), and 15\% soybean meal were barrel temperatures between $123.2-140.0{ }^{\circ} \mathrm{C}$ and feed moisture between $24.5-30.0 \%$. In addition, the extruded pellets from the optimal processing region were probably not completely degraded, as shown by viscosity, DSC, SEM, and $\mathrm{X}$-ray Diffraction analysis. The expanded pellets obtained in the optimal region showed better values of $\mathrm{EI}$ and $\mathrm{ApD}$ with respect to commercial wheat expanded pellets. The prepared expanded pellets may have an advantage due to the nutritional contribution provided by the addition of QPM and SM.

\section{Acknowledgements}

The authors are grateful to the Food Science and Technology Department of the Sinaloa State University and CINVESTAV-QRO for the providing the facilities that allowed the accomplishment of the present study and acknowledge the Master's scholarship provided by CONACYT to the first author.

\section{References}

ALAVI, S. H. et al. Structural properties of protein-stabilized starch-based supercritical fluid extrudates. Food Research International, v. 32, p. 107-118, 1999. http://dx.doi.org/10.1016/ S0963-9969(99)00063-0

ASCHERI, J. L. R. et al. Efecto de la formulación sobre la expansión y viscosidad de "snacks" (pellets) producidos por extrusión termoplástica. Alimentaria, v. 33, n. 286, p. 111-117, 1995.

ASSOCIATION OF OFFICIAL ANALYTICAL CHEMISTS AOAC. Official methods of analysis. 15. ed. Arlington: AOAC International, 1990.

BASTOS-CARDOSO, I. et al. Development and characterization of extruded pellets of whole potato (Solanum tuberosum L.) flour expanded by microwave heating. Cereal Chemistry, v. 84 , n. 2, p. 137-144, 2007. http://dx.doi.org/10.1094/CCHEM-84-2-0137

BATTERMAN-AZCONA, S. J.; LAWTON, J. W.; HAMAKER, B. R. Effect of specific mechanical energy on protein bodies and a-zein in corn flour extrudates. Cereal Chemistry, v. 76, n. 2, p. 316-320, 1999. http://dx.doi.org/10.1094/CCHEM.1999.76.2.316

BHATTACHARYA, S.; PRAKASH, M. Extrusion of blends of rice and chickpea flours: a response surface analysis. Journal Food Engineering, v. 21, p. 15-30, 1994. http://dx.doi.org/10.1016/02608774(94)90076-0 
BJARNASON, M.; VASAL, S. K. Breeding of quality protein maize (QPM). In: JANICK, J. (Ed.). Plant breeding reviews. New York: John Wiley \& Sons, Inc., 1992. v. 9, p. 181-216.

BOISCHOT, C.; MORARU, C. I.; KOKINI, J. L. Factors that influence the microwave expansion of glassy amylopectin extrudates. Cereal Chemistry, v. 80, n. 11, p. 56-61, 2003. http://dx.doi.org/10.1094/ CCHEM.2003.80.1.56

CAMIRE, M. E.; CAMIRE, A.; KRUMHAR, K. Chemical and nutritional changes in foods during extrusion. Critical Reviews in Food Science and Nutrition, v. 29, p. 35-57, 1990. PMid:2184829. http://dx.doi.org/10.1080/10408399009527513

CASE, S. E.; HAMANN, D. D.; SCHWARTZ, S. J. Effect of starch gelatinization on physical properties of extruded wheat- and cornbased products. Cereal Chemistry, v. 69, n. 4, p. 401-404, 1992.

CHANG, Y. K. et al. Influence of extrusion conditions on cassava starch and soybean protein concentrate blends. Acta Alimentaria, v. 30, n. 2, p. 189-203, 2001.

CHEN, C. M.; YEH, A. L. Expansion of rice pellets: examination of glass transition and expansion temperature. Journal of Cereal Science, v. 32, n. 2, p. 137-45, 2000. http://dx.doi.org/10.1006/jcrs.2000.0332

CHIANG, B. Y.; JOHNSON, J. A. Gelation of starch extruded products. Cereal Chemistry, v. 54, n. 3, p. 436-443, 1977.

ERNOULT, V.; MORARU, C. I.; KOKINI, J. L. Influence of fat on expansion of glassy amylopectin extrudates by microwave heating. Cereal Chemistry, v. 79 , n. 2, p. 265-273, 2002. http://dx.doi. org/10.1094/CCHEM.2002.79.2.265

FAUBION, J. M.; HOSENEY, R. C. High-temperature short-time extrusion cooking of wheat starch and flour I. Effect of moisture and flour type on extrudate properties. Cereal Chemistry, v. 59, n. 6, p. 529-533, 1982.

FLOROS, J. D.; CHINNAN, M. S. Computer graphics-assisted optimization for product and process development. Food Technology, v. 42, n. 2, p. 72, p. 74-78,84, 1988.

GOMEZ, M. H.; AGUILERA, J. M. A physicochemical model for extrusion corn starch. Journal of Food Science, v. 49, p. 40-43, 1984. http://dx.doi.org/10.1111/j.1365-2621.1984.tb13664.x

GUJSKA, E.; KHAN, K. Effect of temperature on properties of extrudates from high starch fractions of navy, pinto bean meal (Phaseolus vulgaris L.). Journal of Food Science, v. 55, n. 2, p. 466-469, 1991. http://dx.doi.org/10.1111/j.1365-2621.1990.tb06788.x

HASHIMOTO, J. M. et al. Effect of processing conditions on some functional characteristics of extrusion-cooked cassava starch/wheat gluten blends. Journal of the Science and Food Agriculture, v. 82, n. 8, p. 924-930, 2002. http://dx.doi.org/10.1002/jsfa.1123

HOLLINGSWORTH, P. Third-generation snacks take aim at popcorn market. Food Technology, v. 55, p. 20, 2001

KNUTSON, C. A. A simple colorimetric procedure for determination of amylose in maize starches. Cereal Chemistry, v. 63, p. 89-92, 1986.

LEE, E. Y. et al. Effects of gelatinization and moisture content of extruded starch pellets on morphology and physical properties of microwave-expanded products. Cereal Chemistry, v. 77, n. 6, p. 769-773, 2000. http://dx.doi.org/10.1094/CCHEM.2000.77.6.769

LEE, E. Y.; RYU, G. H.; LIM, S. T. Effects of processing parameters on physical properties of corn starch extrudates expanded using supercritical CO2 injection. Cereal Chemistry, v. 76, n. 1, p. 63-69, 1999. http://dx.doi.org/10.1094/CCHEM.1999.76.1.63

LI, M.; LEE, T. C. Effect of cysteine on the functional properties and microstructures of wheat flour extrudates. Journal of Agriculture and Food Chemistry, v. 44, n. 7, p. 1871-1880, 1996. http://dx.doi. org/10.1021/jf9505741

MADEKA, H; KOKINI, J. L. Effect of addition of zein and gliadin on the rheological properties of amylopectin starch with low-to-intermediate moisture. Cereal Chemistry, v. 69, n. 5, p. 489-494, 1992.

MAGA, J. A.; LIU, M. B. Hopi blue corn extrusion. Developments in Food Science, v. 32, p. 983-986, 1993.
MARTINEZ-BUSTOS, F.; FIGUEROA, J. D. C.; LARIOS, S. A. High lysine extruded products of quality protein maize. Journal of the Science and Food Agriculture, v. 71, p. 151-155, 1996. http://dx.doi.org/10.1002/ (SICI)1097-0010(199606)71:2\%3C151::AID-JSFA562\%3E3.0.CO;2-X

MATHEW, J. M.; HOSENEY, R. C.; FAUBION, J. M. Effects of corn hybrid and growth environment on corn curl and pet food extrudates. Cereal Chemistry, v. 76, n. 5, p. 625-628, 1999. http:// dx.doi.org/10.1094/CCHEM.1999.76.5.625

MEUSER, F.; VAN-LENGERICH, B.; GIMMLER, N. Optimization in extrusion. In: ZEUTHEN, P. et al. (Eds.). Processing and Quality of Foods. London: Elsevier Applied Science,1990. chap 1, p. 215-225.

MORARU, C. I., KOKINI, J. L. Nucleation and expansion during extrusion and microwave heating of cereal foods. Comprehensive Reviews in Food Science and Food Safety, v. 2, p. 120-138, 2003. http://dx.doi.org/10.1111/j.1541-4337.2003.tb00020.x

ONWULATA, C. I. et al. Physical properties of extruded products as affected by cheese whey. Journal of Food Science, v. 63, n. 5, p. 814-818, 1998. http://dx.doi.org/10.1111/j.1365-2621.1998.tb17906.x

ONWULATA, C. I. et al. Physical properties of extruded products as affected by cheese whey. Lebensmittel-Wissenschaft undTechnologie, v. 34, n. 7, p. 424-429, 2001.

POTTER, S. M. Soy proteins and cardiovascular disease: the impact of bioactive components in soy. Nutrition reviews, v. 56, p. 231-235, 1998. http://dx.doi.org/10.1111/j.1753-4887.1998.tb01754.x

SAN MARTIN-MARTINEZ, E. et al. Selective nixtamalization of fractions of maize grain (Zea mays L.) and their use in the preparation of instant tortilla flours analyzed using response surface methodology. Cereal Chemistry, v. 80, n. 1, p. 13-19, 2003. http:// dx.doi.org/10.1094/CCHEM.2003.80.1.13

SINGH, N. et al. Physical properties of extruded wheat starch-additive mixtures. Cereal Chemistry, v. 75, n. 3, p. 325-330, 1998. http:// dx.doi.org/10.1094/CCHEM.1998.75.3.325

SPRATT, W. A.; TIMBERS, G. E.; PATON, D. Microwave-puffable half-products of starch-containing material and their production process. EP0312363, 1988. Equivalente a CA 1319045, US 4990348.

STAT-EASE. Design-expert version 6.0.5. Minneapolis: Stat-Ease, Inc., 2001. East. 2021 Hennepin Ave., Suite 1991., MN 55413.

STATSOFT. STATISTICA for Windows Tulsa: StatSoft, Inc., 1995. Computer program manual. 2325 East 13th Street, Tulsa, OK 74104.

SUKNARK, K.; PHILIPS, R. D.; HUANG, Y. W. Tapioca-fish and tapioca-peanut snacks by twin-screw extrusion and deep-fat frying. Journal of Food Science, v. 64, n. 2, p. 303-308, 1999. http://dx.doi. org/10.1111/j.1365-2621.1999.tb15888.x

SUNDERLAND, R. Production of third-generation snacks. Cereal Food World, v. 41, n. 11, p. 12-14, 1996.

THOMAS, D. J.; ATWELL, W. A. Gelatinization, pasting and retrogradation. In: THOMAS, D. J.; ATWELL, W. A. (Eds.). Starches, practical guides for the food industry. St. Paul: Eagan press, 1997. p. 25-30.

VAN HUlle, G. J.; ANKER, C. A.; FRANSSELL, D. E. Food composition and method for preparing cheese-coated, puffed snacks upon microwave heating. US 4251551, 1981.

WANG, S. S. et al. Kinetics of phase transition of waxy corn starch at extrusion temperatures and moisture contents. Journal of Food Science, v. 54, n. 5, p. 1298-1301, 1326, 1989.

ZAZUETA-MORALES, J. J. et al. Effect of the addition of calcium hydroxide on characteristics of extruded products from blue maize (Zea maiz L.) using response surface methodology. Journal of the Science and Food Agriculture, v. 81, n. 14, p. 1379-1386, 2001. http://dx.doi.org/10.1002/jsfa.951

ZENG, M. et al. Sources of Variation for Starch Gelatinization, Pasting, and Gelation Properties in Wheat, Cereal Chemistry, v. 74, n. 1, p. 63-71, 1997. http://dx.doi.org/10.1094/CCHEM.1997.74.1.63 